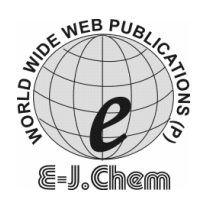

ISSN: 0973-4945; CODEN ECJHAO

E-Journal of Chemistry

http://www.e-journals.net 2009, 6(3), 898-904

\title{
Assessment of Quality of Groundwater in Kandarvakottai and Karambakudi Areas of Pudukkottai District, Tamilnadu, India
}

\author{
D. ILANGESWARAN, R. KUMAR and D. KANNAN \\ Department of Chemistry, \\ J. J. College of Arts and Science, Pudukkottai- 622 404, India. \\ dilangeswaran@yahoo.co.in
}

Received 4 May 2008; Accepted 5 July 2008

\begin{abstract}
Various samples of groundwater were collected from different areas of Kandarvakottai and Karambakudi of Pudukkottai District, Tamilnadu and analyzed for their physicochemical characteristics. The results of this analysis were compared with the water quality standards of ISI, WHO and CPHEEO. In this analysis the various physicochemical parameters such as $\mathrm{pH}$, electrical conductivity, turbidity, total dissolved solids, $\mathrm{Cl}^{-}, \mathrm{F}^{-}, \mathrm{SO}_{4}{ }^{2-}, \mathrm{PO}_{4}{ }^{3-}, \mathrm{NO}_{3}{ }^{-}, \mathrm{NO}_{2}{ }^{-}$, $\mathrm{CN}^{-}, \mathrm{Na}^{+}, \mathrm{K}^{+}, \mathrm{NH}_{3}, \mathrm{Mn}, \mathrm{Fe}, \mathrm{Ca} \& \mathrm{Mg}$ hardness etc., were determined using standard procedures. The quality of groundwater samples were discussed with respect to these parameters and thus an attempt were made to ascertain the quality of groundwater used for drinking and cooking purposes in and around Kandarvakottai and Karambakudi areas.
\end{abstract}

Keywords: Water quality standards, Physicochemical parameters, Quality of groundwater.

\section{Introduction}

Water sources available for drinking and other domestic purposes must possess high degree of purity, free from chemical contamination and microorganisms. But the rapid increase in population and industrialization together with the lack of wisdom to live in harmony with nature has led to the deterioration of good quality of water thus resulting in water pollution. Therefore, pollution of water resources needs a serious and immediate attention through periodical checkup of water quality.

The present study aims at the assessment of water quality in Kandarvakottai and Karambakudi areas of Pudukkottai District, where about 23,000 and 25,000 peoples are living respectively. Agriculture is the main occupation of the people residing there. They cultivate coconut, paddy, banana etc. Bore well water is used for irrigation as well as 
drinking and cooking purposes. Even though all kinds of requirements are met by the ground water, the status of the water is a factor to be considered. Even though there are no major industries to concern, this area lacks proper drainage system and all the domestic sewage are drained in to the nearby canals, which are closer to the bore-well point at some places. Also, the use of fertilizers and pesticides may leave their residual amounts, which along with the domestic wastes percolate in to the ground, getting mixed with groundwater and may affect the quality in a severe manner. Hence, it becomes essential to assess the quality of drinking water in this area.

In this present study, water samples were collected from the bore wells of different areas in and around the Kandarvakottai and the various villages of Karambakudi union in Pudukkottai District and various physical and chemical parameters were determined and the results were compared with the values of various water quality Standards such as Indian Standard Institute (ISI), World Health Organization (WHO), and Central Public Health and Environmental Engineering Organization (CPHEEO).

\section{Experimental}

The samples were collected from the bore wells of various localities of Kandarvakottai and Karambakudi areas and during this collection the distance between one and other location was maintained at a minimum of one kilometer in order to carry out a broad study on the quality of water in this area.

\section{Collection of samples}

Various water samples from different sites were collected in clean and dry polyethylene bottles during July - August 2007. After the collection the samples are immediately preserved in dark boxes and processed for the different analysis within 6 hours after collection.

\section{Phsicochemical analysis}

The samples collected were analyzed for important physical and chemical parameters such as $\mathrm{pH}$, Electrical conductivity (E.C.), turbidity, total dissolved solids (T.D.S.), total hardness (T.H.), $\mathrm{Ca}^{2+}, \mathrm{Mg}^{2+} \mathrm{Cl}^{-}, \mathrm{F}, \mathrm{SO}_{4}{ }^{2-}, \mathrm{PO}_{4}{ }^{3-}, \mathrm{NO}_{3}{ }^{-}, \mathrm{NO}_{2}{ }^{-}, \mathrm{CN}^{-}, \mathrm{Na}^{+}, \mathrm{K}^{+}, \mathrm{NH}_{3}, \mathrm{Mn}$, and $\mathrm{Fe}$ as per the procedures given in "Standard methods for the examination of water and waste water", American Public Health Association (APHA) ${ }^{1}$. The parameters seen in the samples of water were determined by following various methods ${ }^{2-4}$. The $\mathrm{pH}$ and fluoride ion concentration were measured as per the procedures given in Vogel's Textbook of Quantitative Chemical Analysis 5 . Electrical conductivity was measured using an Elico CM- 180 conductivity meter and sulphate concentration by turbidimetric method using a spectronic-20 (Bosch and Lamb, USA) ${ }^{6}$.

\section{Results and Discussion}

The various physical and chemical parameters determined for the water samples were given in Tables 1 and 2 respectively. The samples 1-10 represent the water samples collected from Kandarvakottai area while the samples 11-20 are that of collected from Karambakudi union area. From the analyzed results it was found that the quality of water considerably varies from location to location. As far as the physical parameters are concerned all the twenty samples were appeared colorless and have a relatively constant $\mathrm{pH}$ of around 6.5 to 8.1 (Figure 1). This shows that all the samples are existed within the minimum and maximum tolerable limits of ISI, WHO and CPHEEO standards. The water samples collected near Narikollaipatti and Sempattividuthi were found to be slightly basic. The turbidity level of all the samples were also seen well below the permissible limits of various standards. 
Table 1. Physical parameters of water samples collected in and around Kandarvakottai and Karambakudi areas. 
Table 2. Chemical parameters of water samples (The values are expressed in the unit of ppm).

\begin{tabular}{|c|c|c|c|c|c|c|c|c|c|c|c|c|c|c|c|c|c|c|c|c|c|c|c|c|}
\hline$\underset{\dot{z}}{\dot{z}}$ & 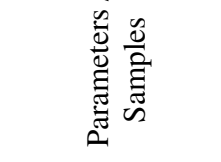 & $\begin{array}{l}7 \\
1 \\
n\end{array}$ & $\begin{array}{l}1 \\
1 \\
n\end{array}$ & $\begin{array}{l}n \\
1 \\
\text { is }\end{array}$ & $\begin{array}{l}+ \\
1 \\
\text { is }\end{array}$ & $\begin{array}{l}n \\
1 \\
n\end{array}$ & $\begin{array}{l}0 \\
1 \\
\text { is }\end{array}$ & $\begin{array}{r}i \\
1 \\
\text { ns }\end{array}$ & $\begin{array}{l}\infty \\
1 \\
n\end{array}$ & $\begin{array}{l}\hat{i} \\
\text { in }\end{array}$ & $\begin{array}{l}0 \\
1 \\
\text { is }\end{array}$ & $\begin{array}{l}= \\
1 \\
\text { is }\end{array}$ & $\begin{array}{l}\simeq \\
1 \\
\text { is }\end{array}$ & $\frac{n}{1}$ & $\begin{array}{l} \pm \\
1 \\
\text { in }\end{array}$ & $\begin{array}{l}n \\
1 \\
\text { in }\end{array}$ & $\begin{array}{l}0 \\
1 \\
1 \\
\text { in }\end{array}$ & $\begin{array}{l}1 \\
1 \\
n\end{array}$ & $\frac{\infty}{1}$ & $\begin{array}{l}a \\
1 \\
\text { is }\end{array}$ & $\begin{array}{l}\text { ते } \\
\text { is }\end{array}$ & $\bar{\Omega}$ & $\stackrel{0}{\stackrel{1}{3}}$ & 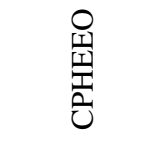 \\
\hline & T.D.S, ppm & 790 & 718 & 626 & 344 & 630 & 932 & 948 & 1160 & 1524 & 378 & 679 & 140 & 297 & 454 & 215 & 162 & 171 & 243 & 268 & 651 & - & $500-1500$ & $500-1500$ \\
\hline & Total Alkalinity & 321 & 319 & 312 & 319 & 311 & 325 & 320 & 314 & 318 & 286 & 314 & 69 & 135 & 184 & 114 & 85 & 73 & 158 & 194 & 295 & & & \\
\hline & Total Hardness & 372 & 263 & 224 & 102 & 284 & 386 & 318 & 64 & 370 & 418 & 188 & 73 & 151 & 229 & 115 & 89 & 97 & 138 & 125 & 146 & & $100-500$ & $200-600$ \\
\hline 4 & $\begin{array}{l}\text { Calcium } \\
\text { Hardness }\end{array}$ & 118 & 86 & 73 & 28 & 102 & 135 & 94 & 20 & 189 & 132 & 46 & 16 & 40 & 36 & 35 & 24 & 80 & 60 & 80 & 10 & $\begin{array}{l}100- \\
500\end{array}$ & & 200 \\
\hline & $\begin{array}{l}\text { Magnesium } \\
\text { Hardness }\end{array}$ & 18 & 12 & 11.5 & 7.2 & 9.6 & 19 & 22 & 3 & 13 & 20 & 17 & 8 & 12 & 33 & 27 & 8 & 10 & 21 & 23 & 32 & $30-50$ & & 150 \\
\hline 6 & Sodium & 72 & 42 & 102 & 100 & 79 & 76 & 133 & 66 & 144 & 65 & 118 & 14 & 32 & 58 & 13 & 12 & 12 & 13 & 12 & 29 & & 200 & \\
\hline & Potassium & 3 & 3 & 1 & 2 & 2 & 4 & 4 & 3 & 3 & 4 & 8 & 1 & 2 & 3 & 3 & 4 & & 4 & 3 & 4 & & & \\
\hline & Iron & 0 & 0 & 0 & 0 & 0 & 0 & 0 & 0.4 & 0 & 0 & 0 & 0 & 0 & 0 & 0 & 0 & & 0 & 0 & 0 & & $<0.1$ & 1 \\
\hline & Manganes & 0 & 0 & 0 & 0 & ( & 0 & 0 & 0 & 0 & ( & 0 & 0 & ( & 0 & 0 & & & 0 & 0 & & & 0.1 & 0.5 \\
\hline & Free Ammonia & 0 & 0.33 & 0 & 0.21 & 0 & 0 & 0 & 1.3 & 0.3 & 0 & 0 & 0 & 0 & 0 & 0.02 & 0.01 & 0.01 & 0 & 0.02 & 0 & & & \\
\hline & Nitrite & 0 & 0 & 0.1 & 0 & 1 & 0 & 0 & 0 & 0 & 0.07 & 0.06 & 0 & 0.01 & 0 & 0 & 0 & 0 & 0.05 & 0 & 0.09 & & $<0$ & \\
\hline & Nitrate & 13 & 4 & 2 & 0 & 35 & 1 & 13 & 1 & & 57 & 2 & 0 & 2 & 1 & 0 & & & 2 & 1 & 4 & & & \\
\hline & Chl & 112 & 164 & 103 & 45 & 118 & 126 & 130 & 80 & 168 & 114 & 111 & 24 & 36 & 87 & 30 & 20 & 30 & 30 & 30 & 50 & 600 & $200-600$ & 1000 \\
\hline & Fluoride & 0.9 & 0.4 & 0.1 & 0.1 & 0.2 & 0.9 & 0.4 & 0.2 & 0.4 & 0.8 & 1.5 & 0 & 0.2 & 0.2 & 0.04 & 0.06 & 0.1 & 1.0 & 0.5 & 0.15 & 3 & & 1.5 \\
\hline & $\mathrm{Su}$ & 10 & 36 & 18 & 5 & 1 & 14 & 45 & 6 & 37 & 6 & 39 & 5 & 10 & 19 & 32 & 8 & 24 & 16 & 4 & 12 & 1000 & $200-400$ & 400 \\
\hline & Phosphate & 0 & 0.21 & 0 & 0 & 0.2 & 0 & 0.3 & 0 & 0 & 0 & 0 & 0.10 & 0 & 0.05 & 0 & 0 & 0.025 & 0 & 0.09 & 0.018 & & & \\
\hline
\end{tabular}




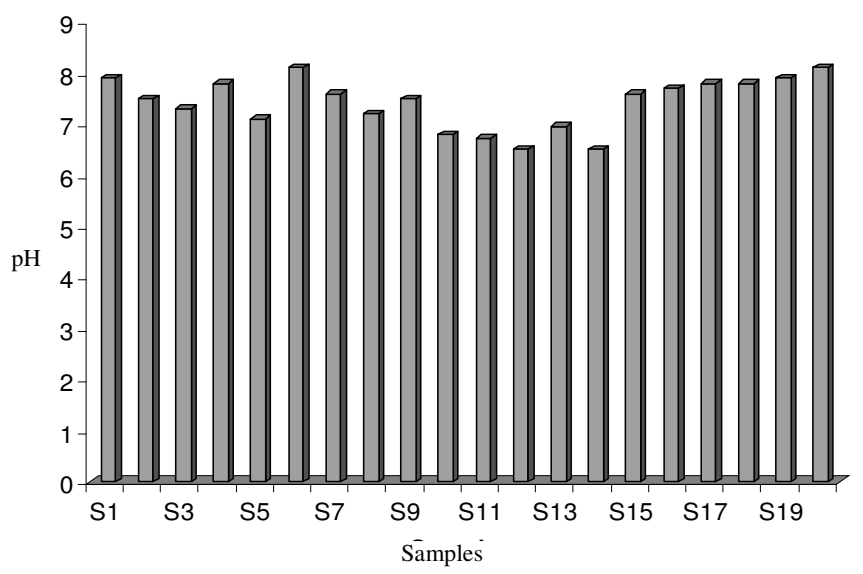

Figure 1. $\mathrm{pH}$ of water samples collected from Kandarvakottai (S1 to S10) and Karambakudi (S11 to S20) areas.

The chemical parameters of these samples were mostly found to be remaining within the permissible limits of various standards. The values of total dissolved solids (TDS) determined for these samples showed that most of the samples collected from the Kandarvakottai area crossed the minimum tolerance limit of $500 \mathrm{ppm}$ of both WHO and CPHEEO standards (Figure 2). But, only the sample collected near Vadugapatti exceeds the maximum permissible limit of TDS of $1500 \mathrm{ppm}$ of WHO and CPHEEO standards. Among the samples collected from Karambakudi union, only a very few samples crossed the minimum tolerance limit of TDS and most of the samples from these area got TDS values lesser than the minimum tolerance limit.

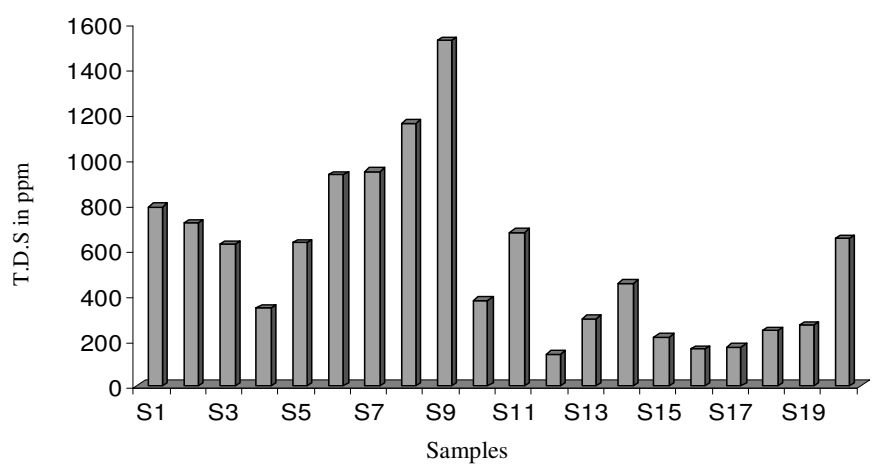

Figure 2. Total dissolved solids (ppm) of water samples collected from Kandarvakottai (S1 to S10) and Karambakudi (S11 to S20) areas.

Approximately $98 \%$ of world's groundwater is dominated by calcium and bicarbonate ions due to the weathering of lime stones in the rain catchments and groundwater beds ${ }^{7}$. The maximum permissible limit for Mg hardness as per the ISI and CPHEEO standards are 50 and $150 \mathrm{ppm}$ respectively. All the samples analyzed have the Mg hardness well below these limits. As far as the Ca hardness is concerned the maximum tolerance limit is 500 and 200 ppm for 
ISI and CPHEEO respectively. But none of these samples analyzed exceeds these limits. However fewer samples of Kandarvakottai area exceeded the minimum tolerance limits of $\mathrm{Mg}$ and $\mathrm{Ca}$ hardness (Figure 3) when compared to the samples of Karambakudi area.

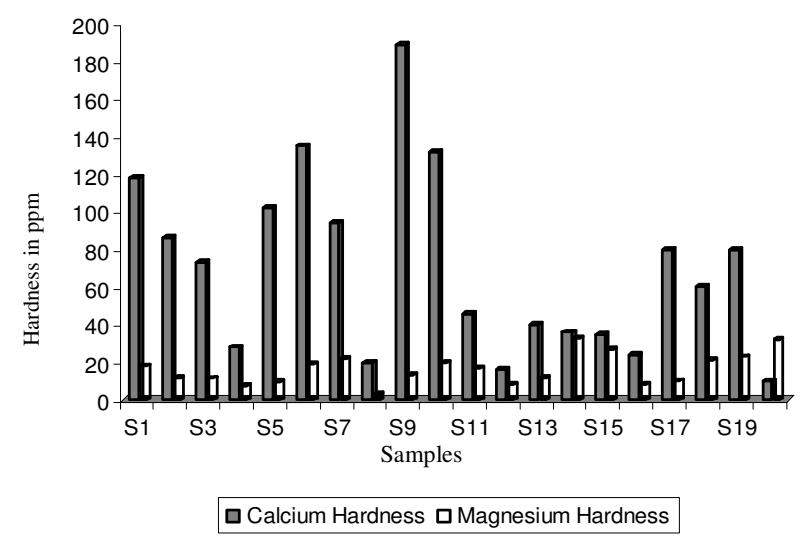

Figure 3. Calcium and magnesium hardness (ppm) of water samples collected from Kandarvakottai (S1 to S10) and Karambakudi (S11 to S20) areas.

The water samples from Kandarvakottai area mostly exceeded the minimum tolerance limit for total hardness of 100 and 200 ppm of WHO and CPHEEO standards respectively. But none of the samples cross the maximum permissible limits of 500 and $600 \mathrm{ppm}$ of WHO and CPHEEO standards (Figure 4).

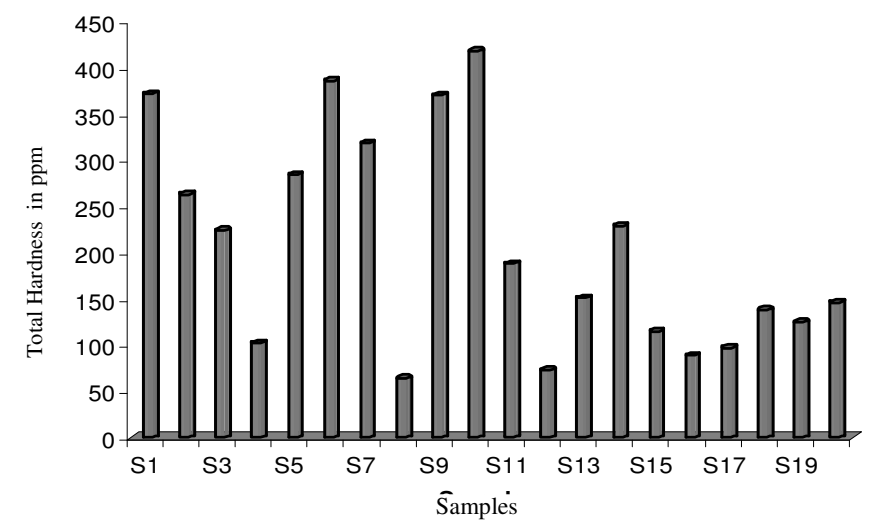

Figure 4. Total Hardness (ppm) of Water Samples Collected from Kandarvakottai (S1 to S10) and Karambakudi (S11 to S20) areas.

Even though the samples of Kandarvakottai area having the concentrations of $\mathrm{Na}^{+}$and $\mathrm{Cl}^{-}$ions (Figure 5) comparatively higher than the samples of Karambakudi union, none of them exceeded the minimum permissible limits of various standards. Similarly the concentrations of other ions such as $\mathrm{F}^{-}, \mathrm{SO}_{4}{ }^{2-}, \mathrm{PO}_{4}{ }^{3-}, \mathrm{NO}_{3}{ }^{-}, \mathrm{NO}_{2}^{-}, \mathrm{K}^{+}, \mathrm{NH}_{3}, \mathrm{Mn}$, and Fe were seen well below the permissible limits of various standards for water quality. 


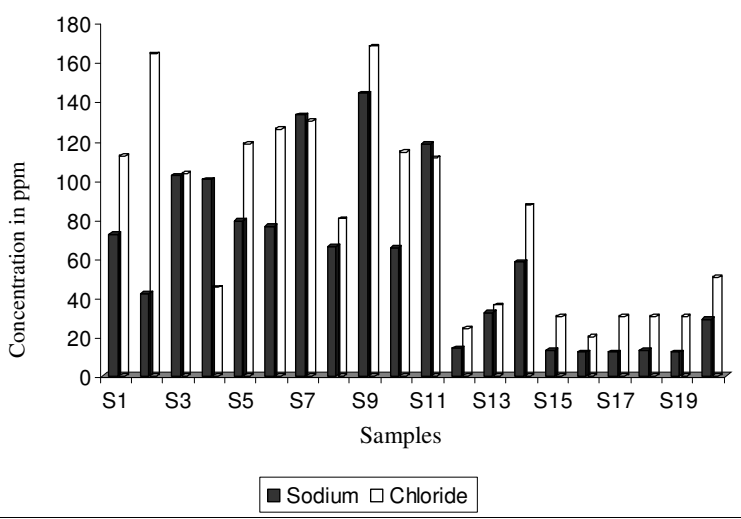

Figure 5. Concentration of sodium and chloride ion (ppm) of water samples collected from Kandarvakottai (S1 to S10) and Karambakudi (S11 to S20) areas.

Due to the absence of chemical industries in the near by places of this study area, no cyanide was identified even in trace amounts. The fluoride ion concentrations of these samples were very low and all these facts showed a good sign for the usage of this water for drinking and cooking purposes.

\section{Conclusion}

The groundwater samples collected from the various places in and around Kandarvakottai and Karambakudi areas of Pudukkottai district of Tamilnadu were analyzed for various phsicochemical parameters such as $\mathrm{pH}$, Electrical conductivity (E.C.), turbidity, total dissolved solids (T.D.S.), total hardness(T.H.), $\mathrm{Ca}^{2+}, \mathrm{Mg}^{2+} \mathrm{Cl}^{-}, \mathrm{F}^{-}, \mathrm{SO}_{4}{ }^{2-}, \mathrm{PO}_{4}{ }^{3-}, \mathrm{NO}_{3}^{-}, \mathrm{NO}_{2}{ }^{-}, \mathrm{CN}^{-}, \mathrm{Na}^{+}$, $\mathrm{K}^{+}, \mathrm{NH}_{3}, \mathrm{Mn}$, and $\mathrm{Fe}$. Almost all the parameters for most of the samples were reported with lower than the permissible limits of ISI, WHO and CPHEEO standards. The level of these low concentrations of these ions does not have any considerable impact for this water to use for drinking and cooking purposes. According to this study, the groundwater in and around Kandarvakottai and Karambakudi areas is suitable for drinking and other purpose. Generally the water in these study area is not harmful to human beings and however the quality of water in Karambakudi is slightly superior to that of Kandarvakottai.

\section{References}

1. APHA Standard Methods for Analysis of Water and Wastewater, $18^{\text {th }}$ Ed., American Public Health Association, Inc., Washington DC, 1992.

2. Manivasakam N, Physical and Chemical Examination of Water, Sewage and Industrial Effluents, $3^{\text {rd }}$ Ed., Pragati Prakashan, Meeret, India, 1996.

3. Nagarajan S, Swaminathan M and Sabarathinam P. L, Poll Res., 1993, 12(4), 245-250.

4. Standard Methods for the Examination of Water and Wastewater, APHA, $16^{\text {th }}$ Ed., Washington DC, 1985.

5. Vogel's Text Book of Quantitative Chemical Analysis, Jeffery G. H, Basset J, Mendham J and Denny R C, $5^{\text {th }}$ Ed., ELBS, 1989.

6. Hart V, Jonson C E and Letterman R D, J Amer Water Works Assoc., 1992, 84(12), 40.

7. Meybeck M, Rev Geol Dyn Geogr Phys., 1979, 21, 215-246.

8. Palanisamy P N, Geetha A, Sujatha M, Sivakumar P and Karunakaran K, E J Chem., 2007, 4(3), 434-439. 


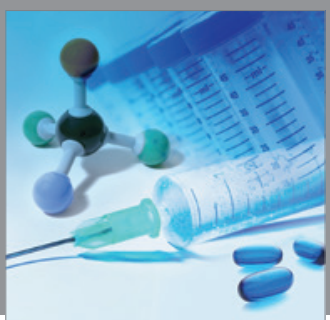

International Journal of

Medicinal Chemistry

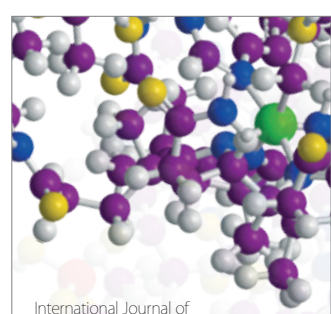

Carbohydrate Chemistry

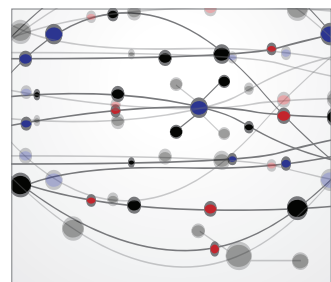

The Scientific World Journal
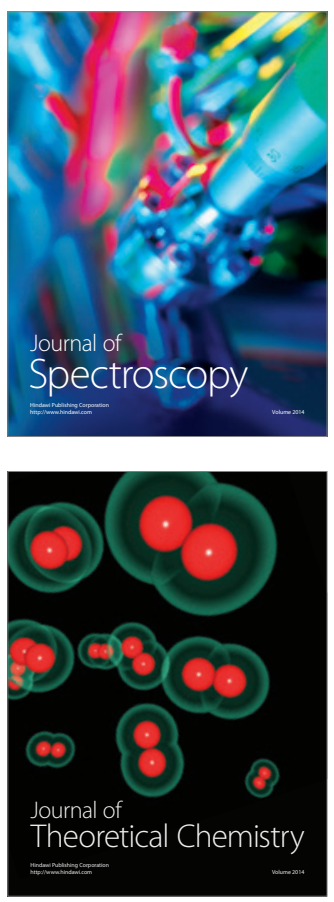
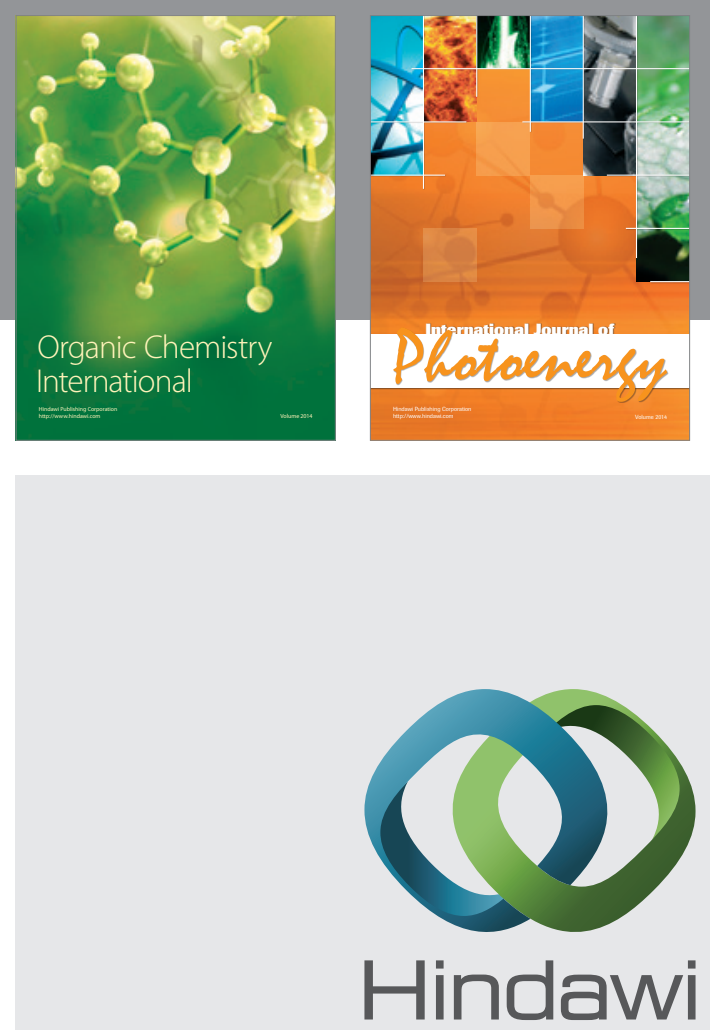

Submit your manuscripts at

http://www.hindawi.com
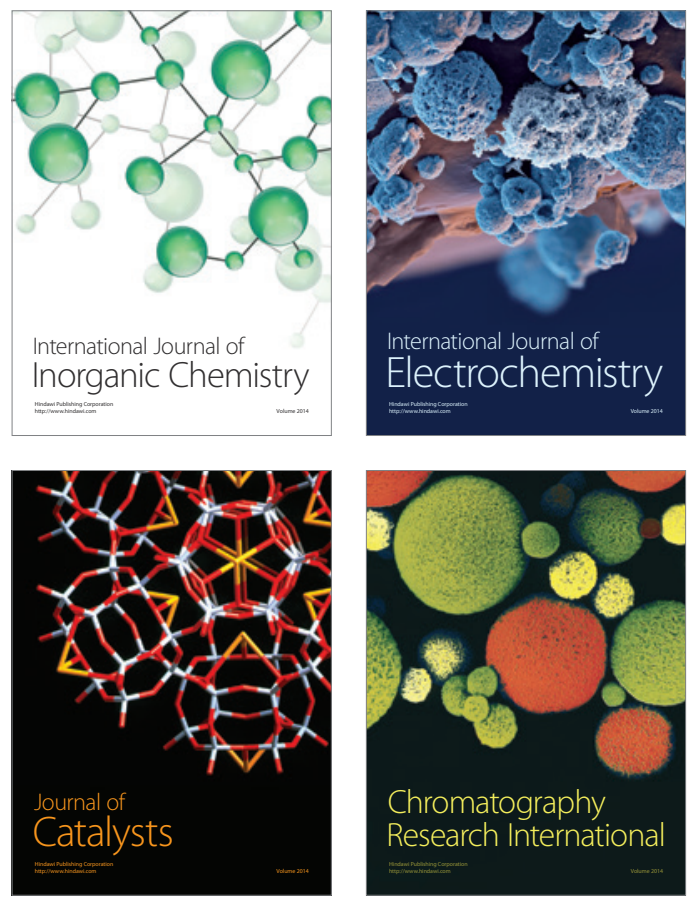
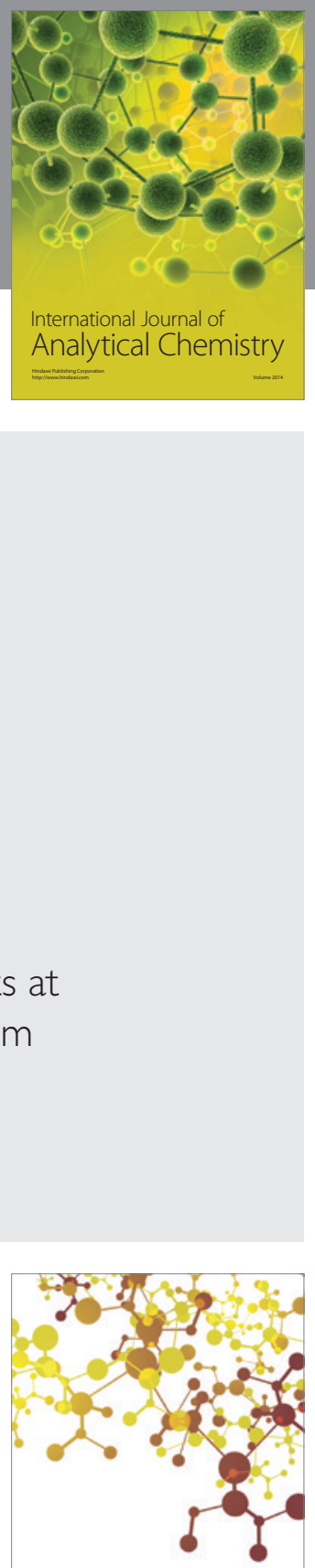

Journal of

Applied Chemistry
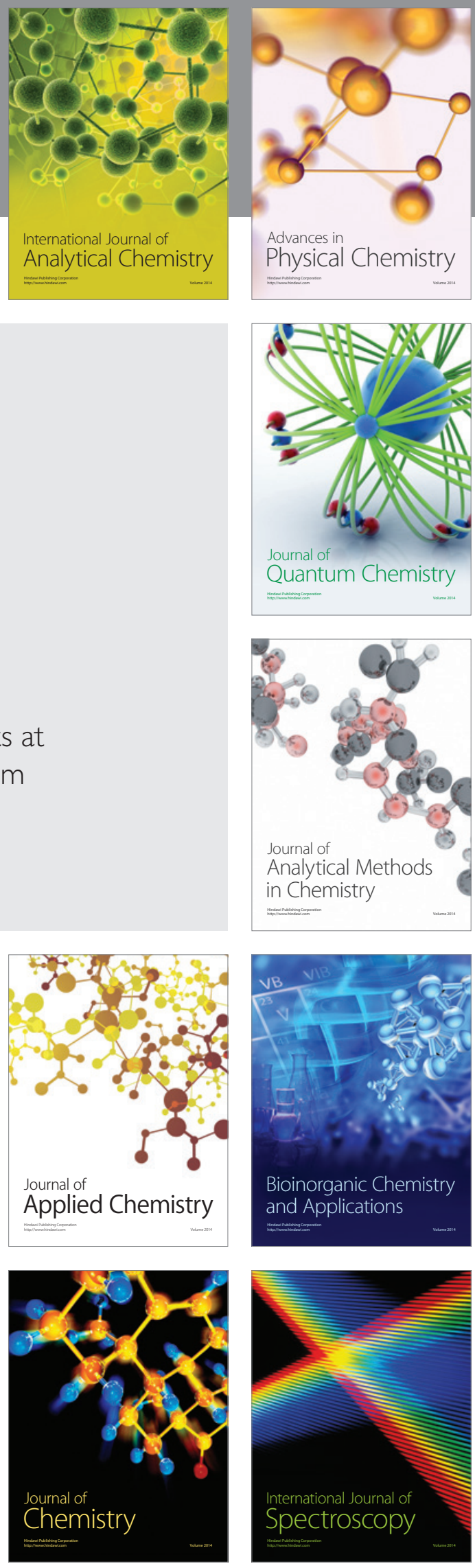